\title{
Methods in water conservation as part of green building rating tools in indonesia - case study: Design of integrated classrooms building in Universitas Negeri Malang, Indonesia
}

\author{
Apif M. Hajji ${ }^{1, *}$, Bambang Suprianto ${ }^{1,2}$, and Dian Ariestadi ${ }^{1}$ \\ ${ }^{1}$ Civil Engineering Department, Universitas Negeri Malang, 65145 Malang, Indonesia \\ ${ }^{2}$ Project Implementation Unit (PIU), the Islamic Development Bank (IDB) 4-in-1 Project, Universitas \\ Negeri Malang, 65145 Malang, Indonesia
}

\begin{abstract}
Under support from the Islamic Development Bank (IDB), Universitas Negeri Malang (UM) is going to develop two new integrated classroom buildings, which consist of not only classrooms, but also seminar rooms, laboratories, lecturer's rooms, educational studios, and auditoria. As an approach to make the buildings gaining the green building certificate, the rating tools are selected from the Green Building Council Indonesia (GBCI). One of the parameters used in the rating tools are how the buildings manage its water resources, as rated from water conservation methods and techniques. The purpose of the research is to analyse the design of the new buildings, particularly the methods in water conservation to be rated in greenship for new building design. The data are obtained from all detailed engineering design documents of the buildings, which include working drawings, detailed specifications, and bill of quantity. By using parameters stated in the GBCI's rating tools, methods of water conservation are analysed to gain the targeted score for fulfilling the specific level of greenship.
\end{abstract}

\section{Introduction}

Under the support from the Islamic Development Bank (IDB), Universitas Negeri Malang (UM) is going to build two-identical nine storey integrated classroom buildings. The buildings were designed to have green building certificate by proposing and fulfilling the requirements from the Green Building Council Indonesia (GBCI) rating system. For design recognition (DR) phase, the system requires efforts and measures in water conservation. The paper analyses all design aspects and criteria included in the working drawings, technical specifications, and bill of quantities as provided in the buildings detailedengineering-design (DED). The DED documents will be analysed, particularly on which water conservation techniques and methods are designed. Water conservation in two new classroom buildings is analysed by using the following criteria: water metering, water

* Corresponding author: apif.miptahul.ft@um.ac.id 
calculation, water use reduction, water fixtures, water recycling, alternative water resources, rain water harvesting, and water efficiency landscaping.

\section{Related Studies}

The purpose of a greenship for buildings is to achieve sustainable buildings in terms of health, energy use, and other environmental issues. In some respects, indoor air quality (IAQ), as a subset of indoor environment quality (IEQ), is maintained to get green building certifications [1]. The overall average portion of IAQ to green building is $7.5 \%$. Carbon dioxide (CO2) and Volatile organic compounds (VOCs), formaldehyde are the most frequently considered indoor air pollutants. The rate of emission, ventilation techniques, and indoor air control are the three main methods used in greenship of buildings for IAQ treatment. Some studies evaluated the application of greenship guidelines and assessment criteria in developing countries, particularly for Architecture, Engineering and Construction (AEC) practices [2]. This study focused on Indonesia and Turkey. Findings showed that, at random sampling, innovation roadmaps for greenship guidelines in Indonesia and Turkey are similar. This study findings also have similarities with those in market conditions that would be able to catalyze the innovation in AEC industries both in Turkey and Indonesia. Concerning the sustainable approaches, greenship for building may also be considered as an alternative for overseeing the energy use in developing countries [3]. By investigating green aspects, the study proposed a new set of self-contained factors ensembles measuring greenship for buildings and to contributed a new combined rating tool.

Since 2004, the Indonesian government has promulgated the reduction of carbon emission as an effort for preventing global climate change [4]. This study described, analyzed, and examined constraints and opportunities related to greenship for buildings policy in Indonesia. To support the effort, there is a global campus sustainability rankings in higher education [5]. The study covered a set of analytical overview of UI Green-Metric World University Ranking. The ranking is criticized in relation to the changing concepts of sustainability and the symbiosis between scientific and practical point of views. In Vietnam, economic progress has been giving critical pressure on both infrastructure and environment, particularly in housing demand, energy use, and pollution management [6]. Green building assessment in Vietnam is still considered low because of lacking governmental support. The advance of greenship for buildings has been increasing in both quality and design [7]. Any green building approaches can reduce the energy use especially for air conditioning system. The design of external heat load plays important part in reducing energy for air conditioning system. The external heat load is determined by the selection of wall, glass and roof. Recently, the rise of the environmental issue, such as global climate change and the energy crisis requires the building to perform energy saving measures for reducing the hostile effects on the environment [8]. Developments of greenship for buildings in Indonesia have been showing a remarkable trends in the last 5 years. The Indonesian government has prepared required regulations for implementing the green buildings [9]. Recent studies on the success of the realizations have shown the need of more all-inclusive methods in conveying the green buildings.

In some regions of the world there are variety of built environment characteristics based on their economic, political, and environmental conditions [10]. These countries have various green building platforms for green building rating systems, which include both international and local rating systems. In Indonesia, some approaches used life cost and efficiency factors [11], energy management [12], or life cycle assessment methods [13]. 


\section{Method}

Water conservation in two new classroom buildings is analysed by using the following criteria: water metering, water calculation, water use reduction, water fixtures, water recycling, alternative water resources, rain water harvesting, and water efficiency landscaping. Water metering is used to monitor and control water consumption as a basis for better water management. The installation of water meter in the design phase is analysed by using the following parameters: (1) location of water meter, (2) the range of water meter indicator in the unit of $\mathrm{m}^{3}$, (3) compliance with the SNI 2418.2-2009 and SNI 2547-2008, and (4) the consumption rate plan.

Water calculation in design phase is analysed from the water consumption rate, which is calculated from the following items: (1) water fixtures, that includes water closets, urinal, lavatories, faucets and shower, (2) cooling tower, that is used for 'make-up water' from evaporation process, (3) landscaping, that is used for all plants irrigation and vertical greeneries, (4) extended needs, such as swimming pool (if any), bath tub (if any), and kitchen utilities. Water consumption rate for this section is calculated by using GBCI's water calculation worksheet for simulate the use of water at operational stage. Water use reduction is delivered to improve the water consumption efficiency, and to reduce the sewage as well. The reduction is analysed as part of standard compliance from the SNI 037065-2005.

The analysis of water fixtures is important since this is part of the efforts for obtaining higher efficiency in water consumption rate. The analysis is applied to the following fixtures: (1) water closets with or without flush valve, (2) urinal, (3) lavatories, (4) faucets, (5) shower, (6) pre-rinse spray valve or washer, (7) auto-flush for lavatories, and (8) autostop fixtures for faucets.

\section{Results and Discussion}

\subsection{Water metering}

The setting up of water volume meters placed at water distribution system; one volume meter at the distribution outlet, one volume meter at recycling outlet, and one at the additional distribution outlet. From working drawing and technical specifications of DED, it is observed that: (1) water meter for outlet from deep well is drawn to be installed at domestic ground water tank, (2) water meter for outlet from rainwater tank is drawn to be installed at domestic ground water tank, and (3) condensation water are pooled with rainwater and the meter is going to be installed at ground-rainwater tank. The position and location of water meters are shown in Figure 1. 


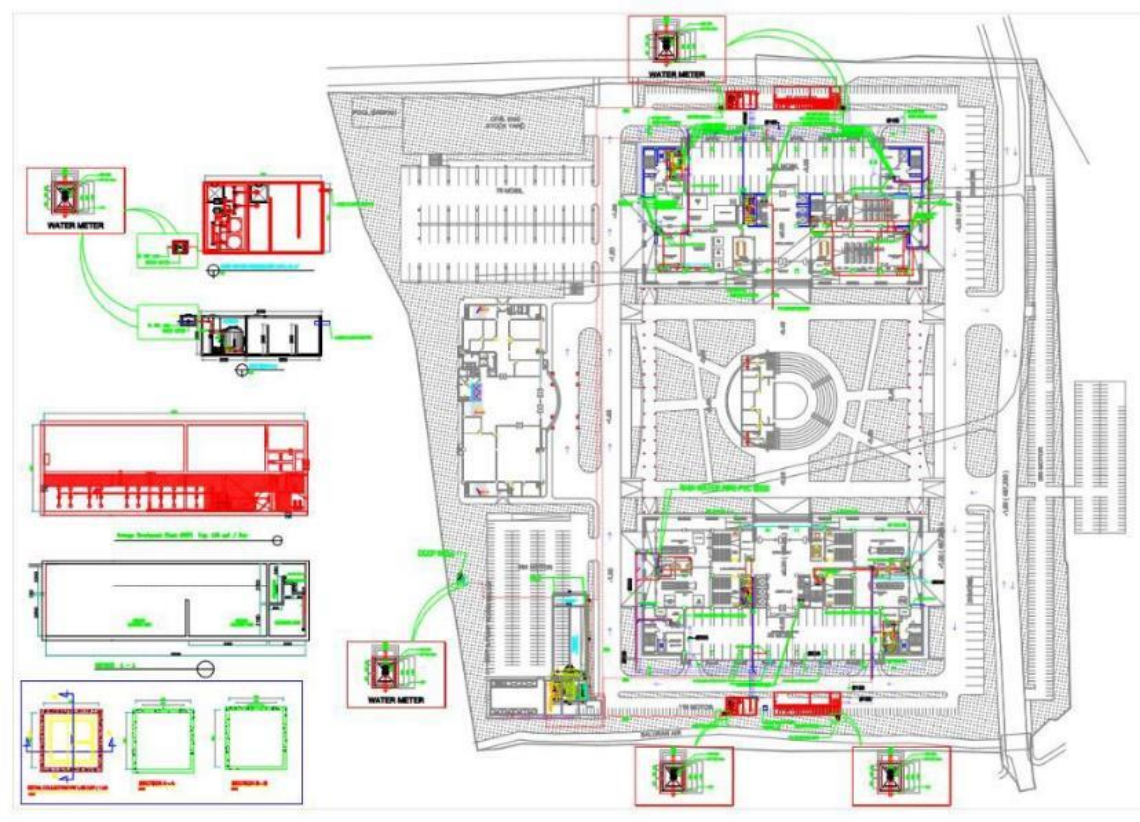

Fig. 1. The location of water meters on building site

\subsection{Water calculation}

Water use in the building was analyzed by using water calculation worksheet provided by GBCI (downloaded as spreadsheet-based user's interface). Water calculation for the buildings is based on net usable area of $19,445 \mathrm{~m}^{2}$, with predicted inhabitants of 1,944 persons, at 10 hours/day of operation. The simulation of water use at building operation is shown on Table 1.

Table 1. Simulation results of water use at building operation

\begin{tabular}{|c|c|c|c|}
\hline $\begin{array}{c}\text { Consumption for water } \\
\text { fixtures }\end{array}$ & $\begin{array}{c}\text { Standard } \\
\text { Baseline (I/day) }\end{array}$ & $\begin{array}{c}\text { Proposed } \\
\text { consumption (l/day) }\end{array}$ & $\begin{array}{c}\text { Efficiency } \\
\text { (l/day) }\end{array}$ \\
\hline Water-closet flush tank & 15,163 & 10,144 & 5,018 \\
\hline Lavatories flush valves & 7,776 & 3,888 & 3,888 \\
\hline Wall faucets & 5,832 & 4,374 & 1,458 \\
\hline Wall-sinks & 5,832 & 4,374 & 1,458 \\
\hline Ablution faucets/valves & 7,776 & 5,832 & 1,944 \\
\hline Landscaping & 101,490 & 101.490 & 0 \\
\hline
\end{tabular}

\subsection{Water use reduction}

From working drawings and technical specifications of DED, it is found that (1) limiting the highest clean water consumption rate at $80 \%$ from primary resource without reducing the needs per person (as stated in national water use standard SNI 03-7065-2005, (2) reducing clean water consumption rate from primary resource by $5 \%$, and (3) reaching the 
clean water use efficiency rate at $60 \%$ of the national water consumption standard (50 liter/person-day)

\subsection{Water fixtures}

To have high efficiency in the installed water fixtures, it is targeted that (1) using water fixtures at $25 \%-75 \%$ lower than the maximum capacity of its water drainage system, (2) water closet is used less than 6 liter/flush, (3) urinal is used less than 4 liter/flush, (4) sink is used less than 8 liter/minute (automatic stop), (5) wall tap for exterior is used less than 8 liter/minute, (6) wall tap for janitor is used less than 8 liter/minute, (7) wall tap for praying room is used less than 8 liter/minute, and (8) shower tap: less than 9 liter/minute. Total water fixtures to be installed in the buildings are shown in Table 2.

Table 2. The number of water fixtures installed

\begin{tabular}{|c|c|c|c|}
\hline Water fixtures & Baseline Capacity & $\begin{array}{c}\text { Proposed } \\
\text { Specification }\end{array}$ & Total \\
\hline WC flush tank - sitting & $61 /$ flush & $3.31 /$ flush & 89 \\
\hline WC flush tank - squatting & $61 /$ flush & $61 /$ flush & 32 \\
\hline Urinoir & $41 /$ flush & $21 /$ flush & 62 \\
\hline Ablution tap/faucet & $81 /$ minute & $61 /$ minute & 16 \\
\hline Sink faucet & $81 /$ minute & $61 /$ minute & 135 \\
\hline Janitor tap & $81 /$ minute & $61 /$ minute & 15 \\
\hline Pantry tap & $81 /$ minute & $61 /$ minute & 2 \\
\hline
\end{tabular}

The total water fixtures to be installed in the buildings are 319 units. It is more efficient that those on the base line, which is 351 units, and according to the GBCI rating system, it achieves $90.8 \%$ of efficiency. Some examples of water fixture are shown on Figure 2.
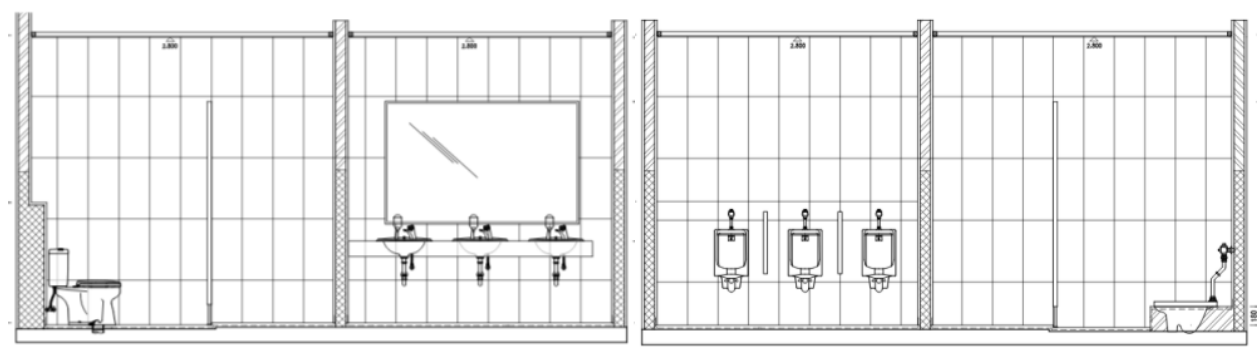

Fig. 2. Section drawings of WC, urinoir, and wall sinks.

\subsection{Alternative water resources}

Integrated classroom buildings in UM use some alternative for water resources: water from air conditioning system condensation, rain water, and water for ablution. The buildings are also designed to harvest rainwater by providing rainwater reservoir with the capacity $50 \%$ $75 \%$ of total rain water drop on the roof by using rain intensity rate at 10 years (on 
average). Rainwater are contained in a reservoir with the capacity of $40 \mathrm{~m} 3$, where 96,164 liter coming from both buildings. By using two reservoirs, total rainwater harvested is about $80 \mathrm{~m} 3$, or equivalent to $83 \%$ of total water volume from both buildings. The detailed drawing of rainwater reservoir is shown in Figure 3.

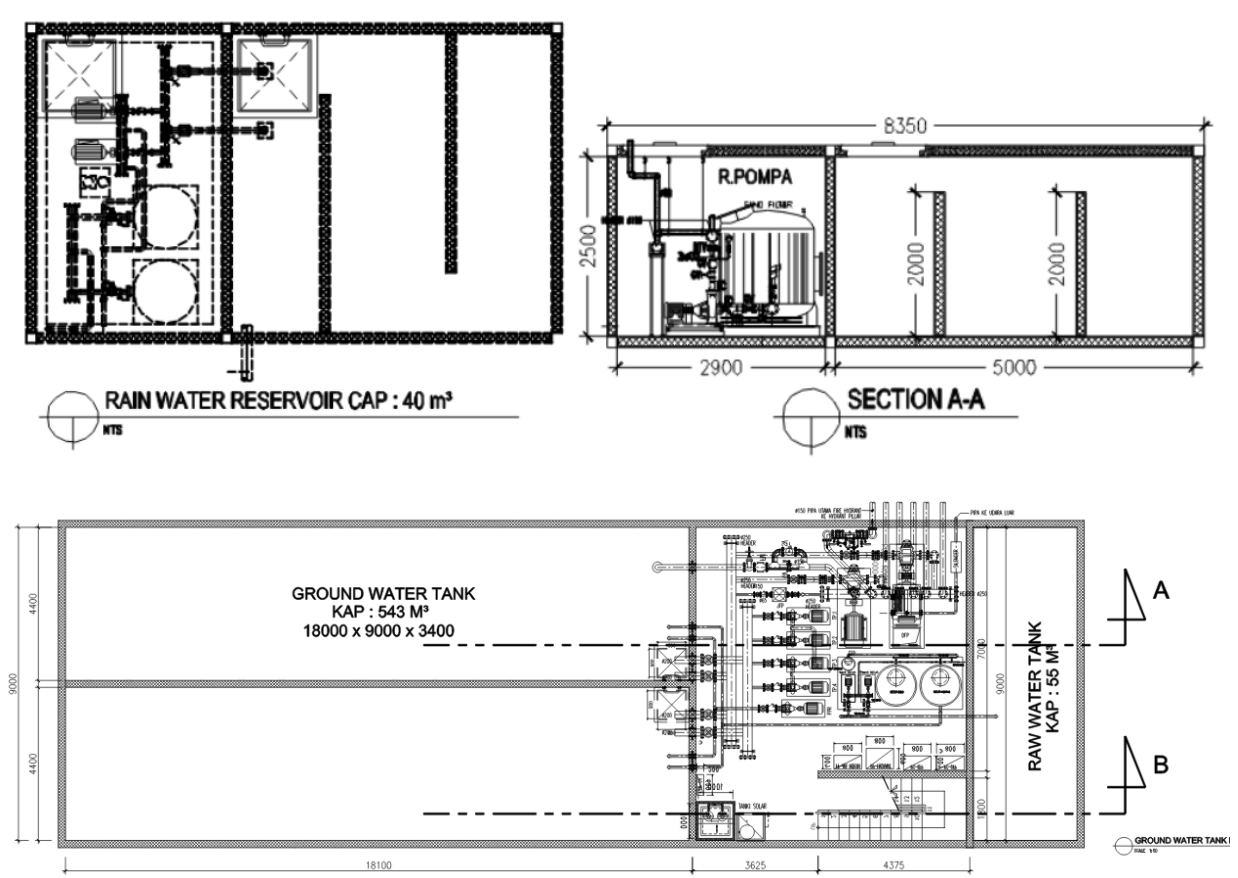

Fig. 3. Detailed drawing of rainwater reservoir

\section{Conclusion}

Water conservation techniques in UM's integrated class building is designated for fostering the awareness the importance of water usage efficiency. As for DR greenship purposes of new building, the water conservation approaches in the buildings is targeted to have points in greenship rating system as follows: (1) water metering and water calculation are mandatory, (2) water use reduction 8 points, (3) water fixtures 3 points, (4) alternative water resources 2 points, and (5) rainwater harvesting 2 points. At the total proposed greenship certificate, this water conservation points for UM's integrated building design will be added to overall point from appropriate site development, energy efficiency and conservation, material resource and cycle, indoor health and comfort, and building environmental management.

\section{References}

1. W. Wei, O. Ramalho, C. Mandin. Building and Environment, 92, 10-19 (2015)

2. S. Mollaoglu, C. Chergia, E. Ergen, M. Syal. Construction Innovation, 16(1), 11-29 (2016)

3. R. Shad, M. Khorrami, M. Ghaemi. Renewable and Sustainable Energy Reviews, 67, 324-340 (2017) 
4. B. Wiryomartono. International Journal of Sustainable Building Technology and Urban Development, 6(2), 82-89 (2015)

5. A. Lauder, R.F. Sari, N. Suwartha, G. Tjahjono, G. Journal of Cleaner Production, 108, 852-863 (2015)

6. H.T. Nguyen, M. Gray. Procedia Engineering, 142, 314-321 (2016)

7. T.R. Biyanto, M.N. Syamsi, H.Y. Fibrianto, N. Afdanny, A.H. Rahman, K. Gunawan, Y.A. Putra. IOP Conference Series: Materials Science and Engineering, 267(1), 012036 (2017)

8. I. Inayati, F.X.N. Soelami, R. Triyogo. Procedia Engineering, 170, 320-324 (2017)

9. M. Abduh. Proceedings of the CIB 2014 Conference, 4-7 (2014)

10. S. Burroughs. Proceedings of the SEB16 Conference (2016)

11. Y. Latief, M.A. Berawi, V. Basten, R. Budiman. Journal of Physics: Conference Series, 877(1), 012041 (2017)

12. M.S. Hidayat. International Journal of Architecture and Urban Development, 6(4), 2129 (2016)

13. V. Basten, Y. Latief, M.A. Berawi, R. Budiman, Riswanto. AIP Conference Proceedings 1818(1), 020008 (2017) 